\title{
Distance Educations for Computers Undeveloped Country Like in Nepal: Prospects and Challenges
}

\author{
Chouhan Tara
}

\begin{abstract}
Broadly, the beginning of Distance Education for Computers dates back to 18th Century due to the phenomenal advancement and innovation in transportation and communication heralded by industrial revolution. DEC as alternative model of education started when technology made it feasible to separate teacher and learner from a fixed place, at a fixed time, to meet a fixed person, in order to be trained.

Started with correspondence mode, DEC is now agreed to have undergone notably four other stages namely multimedia mode, tele-learning model, flexible learning model and interactive flexible learning model. The proliferation suffices to prove why DEC has been so widely accepted in the western hemisphere and why European countries have established and recognized this method through EDEN.
\end{abstract}

Index Terms-Non-Resident Nepali Association, Open University Nepal, proliferated, two-fold availability.

\section{INTRODUCTION}

In Nepalese context, Distance Education offered by the state's own establishment carries no history in the sense that the government's plan to establish Open University Nepal has yet not been materialized. Hence, Distance Education for Computers in relation to Open University Nepal can be discussed only at the level of efforts made. The government's initial endeavor can be located in the very year when Nepali Government became a signatory of South Asian Association for Regional Corporation Consortium to Open and Distance Education in 1999.

Compared to the genesis of DEC in the west, its official and documented history in South Asian Countries, however, carries shorter history. The table below shows the history of open and distance learning in the South Asian Countries.

Though offered very lately, Distance Education for Computers in South Asian Countries has been gaining an increased attention and thereby a phenomenal growth in recent years. The change can best be described as the move of Distance Education for Computers from marginal to integral part of overall educational provision [1].

The Ministry of Education itself constituted a Distance Education for Computers Committee in 1999 under the chairmanship of the Secretary of Education to suggest the government with modalities of Open Learning Distance Education in Nepal. The Committee comprising Open Learning Distance Education experts are suggested the government with alternatives of programs and resources.

Manuscript received September 19, 2013; revised January 3, 2014

Chouhan Tara was with KIST College and Monitoring Officer of Student Financial Assistance Fund Development Board, Nepal (e-mail: kushalch@hotmail.com).
TABLE I: HISTORY OF OPEN UNIVERSITY IN SOUTH ASIAN COUNTRIES

\begin{tabular}{|c|c|c|}
\hline Country & Year & Institute \\
\hline Afghanistan & & None \\
\hline Bangladesh & 1985 & $\begin{array}{l}\text { Bangladesh Institute of Distance } \\
\text { Education / Bangladesh Open } \\
\text { University were established in } 1992 .\end{array}$ \\
\hline Bhutan & & None \\
\hline India & 1982 & $\begin{array}{l}\text { Dr. B.R. Ambedkar Open University, } \\
\text { formerly known as } \\
\text { Andhra Pradesh Open University/ } \\
\text { The National } \\
\text { Open University of India was } \\
\text { established in } 1985 \text {. }\end{array}$ \\
\hline Maldives & 1999 & $\begin{array}{l}\text { Tertiary Institute for Open Learning; } \\
\text { the institute was under } \\
\text { The Maldives National University }\end{array}$ \\
\hline Pakistan & 1974 & Allama Iqbal Open University \\
\hline Sri Lanka & 1980 & Open University of Sri Lanka \\
\hline
\end{tabular}

Ministry of Education and Non-Resident Nepali Association have signed in the agreement to start Open University Nepal move appears visible. The proposed Open University Nepal has included the following major objectives:

- Advance a computer-based education to rural Nepal that relates to health, social-systems, productivity, economic improvement, and sustainability disciplines.

- Close the gap in higher education demand, currently unmet by the combined capacity of all the institutions, through open and distance mechanisms.

- Provide opportunities for teachers and government employees who are unable to advance their education, skills and careers while living in rural and remote places, or to those who are unemployed.

- Provide a mechanism to continue education for the youth who take temporary or permanent employment in foreign countries.

- Take tertiary education to the rural, remote, and marginalized people of Nepal, especially women and Dalits, who are practically confined to the villages due to family obligations, social challenges, and financial constraints.

- The outcome of the effort, however, has been only a ray of hope for the advocates of Distance Education. In a context when the plan is in incubation period, writing on the prospect of Distance Education for Computers might sound highly phantasmagoric [2]. Here, I caution my readers not to harness total skepticism mainly for two reasons: first, the government of Nepal along with a promising partner has declared an Open University as a viable and appropriate means to provide mass access to 
tertiary education; second, Distance Education has already been in operation since the turn of century in Nepal through accredited universities such as Indira Gandhi National Open University.

\section{Modes And Methods of Distance EduCAtion}

Distance learning delivery methods assist the modes of delivery of the courses depending on the nature and demand of the subjects [3]. The different Methods are:

- Study materials in print, electronic, videos, audio cassette.

- TV programs

- Contact sessions

- Part time tutorial sessions

- Telephone tutoring: enquiry reception, support and counseling

- Assignment marking: special attention is given to the evaluation of assignment responses. During assignment marking, comments are made, questions are asked and answers required with their justifications.

- Special seminars on a certain subject in a course with special focus on more difficult subjects.

- Study centers with the facility of libraries and laboratories

\section{IMPORTANCE OF TECHNOLOGIES IN EDUCATION WITH SPECIAL REFERENCE TO NON-FORMAL EDUCATION}

Technology is a scientific way of developing new techniques and a systematic way of evolving and applying these techniques. Education Technology is an application of scientific knowledge about learning and condition of learning to improve the effectiveness and efficiency of education system. It can be considered as the systematic use of scientific method to plan realize and evaluate effective teaching learning process in informal, non-informal and formal education. It is comparatively a new idea that is grown as a result of the integration of technological devices in the use of practice in education.

Electronic devices such as film projectors, tape recorder, television sets and micro computers are mostly practiced and used as teaching tools in education. Non electronic instrumental materials such as books, photograph, poster, charts are also used. Technological devices are now used in large proportion. It has occupied a critically important role in the field of education and almost in the non-formal education. Itsapplication is needed to an individual and society as an effective information tool to support educational development. Now a day's educational technology can be used effectively for non- formal system whatever level it may be. Different instrumental materials such as audio visual media are used to communicate the factual information to the learners. These materials can be capable more accurately and efficiently than the teacher. Thinks seen are mightier than things heard. Visual aids pictures, charts, maps, graphs, photographs, cartoon etc are served through the sense of vision. These materials should provide to adult women's environment. It enhances the adult thinking capacity and helps them to reason things with proper understanding. These materials are usually pleasure to the eye. They help them to think and express new idea. It motivates the class also and added atmosphere to the situation, attention by some attractive features and conveyed the message quickly. Educational Technology requires a lot of change on the part of the instructors. They should be properly trained to participate in the teaching learning activities. Much specialized training is needed especially in non-formalteaching method for successful program. Use of media such as puppet show street drama, role play, songs, dance visualization method etc are free games used in nonformal education classes. Since the adults get bored with traditional teaching, the literacy instructors have to use audio visual materials to attract and sustain learner's interest in the teaching/ learning program.

\section{A. The Main Aims of Education Technology of NFE Program Are}

- To provide appropriately designed situations for learning and teaching.

- To modify the learners environment by presentation of materials by arranging the different learning activities and by organizing the physical and social surrounding of the learner.

The program should be locally planned as often as possible, target group should be included. Target groups are benefited from Educational Technology. Educational Technology for adult education is targeted to those who are working and do not have time go to literacy class. It is particularly important in reaching women who are cultural or religious regions cannot go to literacy class. People who want additional information about that will improve their quality of education.

\section{B. Different New Techniques for Reaching Learner}

There are many Educational Technology Programs that have sought creative for reaching learners that are compatible with the demands on learner's lives. Some are:

1) Public libraries: Public libraries are very common sourceof information in urban areas. It providesnew knowledge and technologies ofadult learner.

2) Mobile libraries: Since, the public libraries are notmostly available in rural areas, mobilelibraries could play a major role replacethe role of public libraries.

3) Educational radios: The most accessible source of newtechnology in education is educationalradios. Even in penetrating hinder line,it is a powerful means of information.

4) Educational television: T.V is being used effectively to replacethe face to face teaching learningsituation and contact.

5) Discussion and demonstration at community meeting: Public meeting in community is verypowerful means of interaction, sharingof experience and convincing thecommunity people.

6) Special supplements in local newspaper andwall newspaper: Occasionally, community people can bereinforced to have new information andknowledge through the specialsupplements in local newspaper andwall newspaper.

7) Linkage with formal school:One of the interesting programs to non-formalgraduate to have 
equivalencylinked with formal school

8) Providing educational materialsfor social organization: Social organization can be enriched byproviding education materials todisseminate new information to thecommunity.

9) Non-formal meeting places: Non-formal communication is the bestcommunication in the world. So, Nonformalmeeting places are the bestplaces for information dissemination.

10)Community learning centers: Since in the village, there are not any permanent infrastructures to continue literacy program andsustain literacy skill after completing certain levelof literacy education. Community LearningCenter could play a role model as a local level infrastructure for local level.

11)Developing of special text booksand learning materials for adultlearners: Most NFE materials are foundprepared based on national andregional context with theconsideration of regional variationand commercial inspiration. There isa need of developing special learningmaterials for adult learners to geartheir spirit toward the education.

12)Folk songs, puppet show, street drama, role play, dance; public festival: In most villages modern and electronic media maynot be existed. But, in order to create motivation andencouragement local activities like folk songs,puppet show, street drama, role play, dance, publicfestival and local cultural program could be used as tools of attracting and sustaining learner interest. These activities could be used in rural areas. As forexample, street drama has becoming very popularmeans of public gathering and informationdissemination.In conclusion above means of technologies could be used in a very role to delivering nonformal education. It not only helps enriched the teaching learning situation of adult butalso provide chance to share learning experience and functional knowledge related to lifefor their daily use.

\section{NON-FORMAL EDUCATION THROUGH DistancE EDUCATION}

Different educational systems are also changing with expansion of EducationTechnology. Everybody realizes that there is inadequacy of face to face system ofeducation. Due to the growing needs of the society, Distance Education Systems cameinto being. In this system learning is not through a teacher but learning process throughInstrumental materials and electronic messages that emanate from the teacher. Teacherand Taught are separated by distance. There is not personal face to face contact on thepart of teaching and learning process. Mass media is utilized. This kind of methodologywould be important to the Non-Formal Education where many youth and adult have got achance to acquire knowledge and skill from distance education. Employed adult alsohave got chance to acquire knowledge from it. Their aspire remains unfulfilled due tolack of time to go regular institution. Here comes Distances Education to help such people. It caters to the needs of such classes of society. Thus, Distance Education complementsthe adult classes of Non-Formal Education. Corresponding materials of distanceeducation are self-instrumental. Radio broadcasts, audio and video cassettes providesacademic support to the learner. Thus, teaching and learning through electronic devices isan effective alternative to the non-formal literacy classes

The technique of distance education has been accepted by community. It would help to bringchange in the disadvantaged peoples. Distance Education would support to non-formallearner.

\section{Challenges}

Challenges in Distance Education for Computers are inherent to the characteristics of this mode. Since it espouses values of flexibility and accessibility, it assumes learners to have sense of both autonomy and responsibility for learning [4]. Before, I discuss on the problems that start due to the collusion of two elements.

Firstly, Internet access is improving rapidly, but is still generally too weak and inconsistent to allow any reliance on net-based learning solutions. Secondly, the academic culture is resistant to the recognition of the value of open-learning degrees, with subsequent difficulties in re-designing course materials for a more educationally flexible, studentCentered learning environment.

Certainly, the ambivalent position of scholars on the degree from Distance Education for Computers and the problems of internet access for learners account as major impediments. Leaving aside the skepticism of these scholars, I concentrate on other more important factors which make DEC more challenging. One of them, as already mentioned props up from the dialectics of autonomy and responsibility. In Nepalese context, learners' autonomy which should be curbed by the sense of responsibility exists in very peculiar situation. Learner's sense of autonomy often overrides their sense of responsibility. Simply stated, many learners tend to carry no responsibility in pedagogic assumptions in DEC. In turn, the tendency might culminate in using DEC as mere formality for awarding and getting certificate.

\section{A. Lack of Electrification}

Distance Education for Computers relies heavily on advancement and proliferated use of media and communication. More specifically, educationists need to rely on novel methods of imparting knowledge such as the internet and e-mail, telephone, CD-ROMs, print materials, video cassettes and video-conferencing. All these devices need uninterrupted supply of electricity, which in Nepalese context sounds highly unlikely. Power cut has been so severe that electricity avails to us in many months only for around 6-8 hours.

\section{B. Un-Conducive Political Environment}

Political environment in Nepal especially after the restoration of Democracy in 1991 has been constantly unstable. The phenomena such as frequent change of governments and thereby blockage of policies formulated by former government has been hindrance for any initiative. Institutions which are already in operation do not generally suffer; but the institutions like Open University Nepal which are in the making face major hindrance due to political instability. 
The education minister makes the commitment, but how long will he stay in the Minister of Education? By the time the university bill is passed by the parliament, he may already have been out of the government because of the fluid politics of Nepal. That means another minister would have to understand the whole process again.

\section{PROSPECTS}

Distance Education for Computers by its nature carries promising features such as egalitarianism, equality of educational opportunities, flexible curricula [5]. Consequently, the mode bears significant potential to widen access to higher education which in Nepalese context has appeared very tough due to various constrains. The following elements appear to create noteworthy scope for Distance Education for Computers.

\section{A. Availability of Learners}

The inability of Nepali government to tackle the consequences of diversity, whether prevalent in the form of extreme economic disparity or geographical inaccessibility or socio-political hierarchies, had stood as a major barrier for a large population in appropriate access to education. Education opportunities were inappropriately decentralized, if not totally centralized, and thus any individual other than well-to-do economic status could not get enrolled for higher qualification. Many people who could not afford to make such bold decision (I am sure this number is large) could hardly own even fundamental qualifications required to take hold of opportunities which were available.

A very paradoxical situation ensnares these people now: they have opportunities but not the required qualifications. The situation thereby produces foundational reason to demand for educational qualification which does not look viable through traditional mode of education. The availability of learners due to this necessity has further increased at the acceleration of peace process. We have a large number of cadres who had joined Maoist revolution after 1996 leaving their studies are now in need of education as they have been placed back to society. The two-fold availability, along with other elements such as outbound mobility of students for foreign universities, would be productive factors in pulling learners to Distance Education for Computers mechanism.

\section{B. Ample Libraries}

Libraries in Nepal have grown phenomenally especially after the restoration of Democracy in 1991. Now, we live the condition neither of a group of young students in 1930 who were charged of sedition as they applied for permission to start a public library nor of students who suffered in 1960 when the king dismissed Nepal's first elected government and closed public libraries established in the fifties. As the study of Koirala and Bird has outlined, post 1991 has provided appropriate environment for, "re-opening of a number of rural community libraries which were closed during monarchy" [6]. Similarly, a large number of International Non-Government Organizations such as Room to Read, and Read Nepal have been asking for government's permission to "support for community libraries".
Consequently, the number of libraries in Nepal has increased from about 400 in 1990 to about 800 in 2003. The quality and quantity of library has further been enhanced both by INGOs like Rural Development and Education and Room to Read, and by foreign mission libraries such as the American Library, British Council Learning Centre, Bharat Sanskritic Kendra.

Though all the libraries, especially the ones located in rural areas, might not have ample and appropriate books, their infrastructure can be used for Distance Education for Computers.

\section{Contribution from Diaspora}

One of the most optimistic aspects in Distance Education for Computers comes from the promise of contribution from Nepali Diasporas. The Diaspora, like the population of this type elsewhere, undergoes ambivalent position: on the one hand, they meagerly wish to return their home country but on the other, they wish to see the country prospered and plan to contribute without returning.

There are a sizable number of highly qualified academics and professionals among Nepalese Diaspora, who are eager to help their motherland. Having benefited originally from the Nepal's investment in public education and having had a first-hand experience of her needs, many of them are also eager to give back to the native land. Several members of this Diaspora group have themselves experienced the hopelessness caused by poverty, have walked barefoot to attend schools in the mountains and plains, and have faced acute shortage of books and other educational facilities when they pursued their education in Nepal. As many of them have succeeded in obtaining world class education in spite of these insurmountable barriers, they understand the pain and frustrations of the rural poor and marginalized groups and their struggle for education, and know that success is still possible. Because of these reasons, they are well suited to help education in Nepal through open and distance learning and support the neediest groups.

\section{CONCLUSION}

The proliferation and thereby acknowledgement of Distance Education for Computers both in developing and developed countries imply the mode's significant potential. However, this does not mean that DEC will replace the traditional mode as euphorically supposed by scholars. In the developing countries like Nepal, Distance Education for Computers has apparent scope due to the availability of learners, accessibility to libraries and promise from prospective collaborators. But, we have challenges such as un-conducive political environment, lack of electrification, skepticism from some scholars regarding the strength of degree making the task of tackling almost herculean.

\section{REFERENCES}

[1] D. Rasali, A. Adhikariand, and P. Dhakal. "A Proposal for Open University for Rural and Marginalized People,” Nepalnews.com., vol. 4, pp. 132, July 2012.

[2] A. Chimpololo, "The Prospects and Challenges of Open Learning and Distance Education in Malawi," World Academy of Science, Engineering and Technology, vol. 6, pp. 66, June 2010.

[3] Special Issue on Introduction of Technologies in Literacy Programme1999, August literacy watch committee of Nepal bulletin no. 12. 
[4] F. Rennie and M. Robin "The Development of Distributed Learning Techniques in Bhutan and Nepal," The International review of Research in Open and Distance Learning, vol. 2, pp. 50, Feb. 2012.

[5] D Keegan, "ZIFF Institute for Research into Distance Education," Distance education technology for the new millennium: compressed video teaching, vol. 5, pp. 45, May 1995.

[6] N. P. Koirala, "Library Development in Nepal: Problems and Prospects," EBHR-38, vol. 5, pp. 302, Feb. 2011.

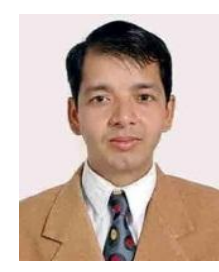

Chouhan Tara was born on January 30, 1978 at Damak, Nepal. He has got the degree in managemen (MBS) at Tribhuvan University of Nepal in March 2002. He was a lecturer of KIST college and Monitoring Officer of Student Financial Assistance Fund Development Board. He was a member of Management Association of Nepal, Nepal Red Cross Society and Reukai Nepal. 